\title{
A Reconceptualised Translation-Based Task as a Viable Teaching Tool in EFL Class to Avoid Calque Errors
}

\author{
Roberto Martínez Mateo ${ }^{1}$ \\ ${ }^{1}$ Faculty of Social Sciences and Humanities, University of Castilla La Mancha, Cuenca, Spain \\ Correspondence: Roberto Martínez Mateo, Faculty of Social Sciences and Humanities, University of Castilla La \\ Mancha, Cuenca, Edificio Gil de Albornoz, Avda. de los Alfares 44, 16071, Spain. Tel: 34-969-179100 (ext. \\ 4339). E-mail: roberto.martinez@uclm.es
}

Received: April 16, $2015 \quad$ Accepted: May 20, $2015 \quad$ Online Published: June 29, 2015
doi:10.5539/elt.v8n7p13 $\quad$ URL: http://dx.doi.org/10.5539/elt.v8n7p13

\begin{abstract}
The negative attitude towards translation as another pedagogical means in Foreign Language Teaching (FLT) has prevailed for much time (Cook, 2010). Nonetheless, currently, many theorists and linguistics agree on the importance of using translation activities in foreign language teaching and underline its beneficial effects to expand vocabulary, to develop writing style and to further understand how languages in contact work (Schäffner, 1998). This paper presents the results of a pilot experience where a reconceptualised role of a translation-based task is implemented in the Foreign Language Teaching (FLT) class and explores the question of whether it can be used as a means to foster the cross-linguistic cognitive processing of languages involved so that this metacognition provided by the translation process will contribute to boost a student's watchfulness and so reduce calque errors when writing (translating) in L2 (English). Under the task-based language teaching methodology, an initiative has been put forward with a group of selected English as an L2 students pursuing a fourfold objective: i) firstly, to reintroduce translation-based tasks as a viable teaching tool in Foreign Language Teaching (FLT) class; ii) secondly, to examine the role of cross-linguistic interference in Second Language Acquisition (SLA) and iii) to identify and tag a specific type of negative interference, namely calque errors, committed by students when translating into L2, and iv) lastly, to check whether this task triggers students' awareness of cross-linguistic differences and similarities and turn this realization into an opportunity to learn (positive interference) by avoiding committing calque errors again.
\end{abstract}

Keywords: Foreign Language Teaching (FLT), translation-based task, linguistic interference, calque, error analysis

\section{Introduction}

In this paper a specific usage of a translation-based activity in the Foreign Language Class (FLT) is described and discussed. For that, it is necessary to take a look back and trace the preceding use of translation. The previous introduction of translation method as a teaching means in SLA took place during the $19^{\text {th }}$ century with the Grammar-Translation (GT) method. Following some decades in which the method flourished, at the turn of the $20^{\text {th }}$ century this methodology was plainly rejected.The passionate rebuff of the GT method led to it being regarded as an outdated and long surpassed methodology. In response, subsequent contemporary Foreign Language methodologies, such as the Direct Method, took a different turn and favoured the exclusive usage of L2 in FLT class. Hence, most foreign language teaching course books are basically driven by the so-called 'monolingual principle' (Howatt, 1994) and, consequently, most existing views in foreign language instruction circles have been against the use of translation as a pedagogical tool (Brown, 2002). Just the mention of this teaching method is instantly associated with the GT methodology and multifarious critics can be stirred up. For this reason, it is not surprising that there has not been much research of the possibilities and potentialities of using translation for instructional purposes in the second language acquisition classroom (Cummins, 2007, p. 227).

However, the monolingual principle, whereby teaching must only be done in the foreign language, has been progressively challenged more frequently. In questioning this assumption, room has been given to include the mother tongue into the FLC. Simultaneously, are-evaluation of L1 use in L2 instruction has been taking place, which has brought about a dramatic shift in the usage of translation in the L2 class (Machida, 2008, p. 142). As a 
result, many linguists agree on the importance of using translation activities in FLT and underline its beneficial effects to increase the literacy skills by expanding vocabulary, developing writing style and further understanding the interaction between languages (Carreres, 2006; Källkvist, 2004; Machida, 2001, 2008; Cook, 2010; Braga \& Maíz, 2013).

The writer of this paper teaches English as a foreign language for an Arts University degree at a Spanish University. A selected group of students from the advanced level class of L2 were chosen to undergo a translation task. This activity was carried out under an internship agreement signed with an archeological park and under the close and thorough supervision of two tutors (one with a Spanish mother tongue and the other with an English mother tongue). The aim of this cooperative project was to complete an inverse translation (Spanish into English) of the park's audio guide text. The teachers were in charge of managing the process and assuring the linguistic quality of the final product and so all the students' final translations were reviewed and proofread. In order to carry out the translation quality assessment, a bilingual revision (Mossop, 2001) was employed to detect errors and modify them accordingly. This professional-like activity as stated by the assignment conditions has, nonetheless, only served instructional purposes for the students who took part in it.

This paper is divided into two parts: the first part gives a full account of the theoretical approach and the second part explains the operational segment. The conceptual part of the paper describes the evolution of the role of students' own language in FLT and advocates the new communicative, cognitive and functional approach taken by translation tasks for FLT pedagogical purposes. Drawing on the scholarly views (Malmkjær, 1998; Cummins, 2007; Carreres, 2006; Machida, 2008, 2011; Cook, 2010; Braga \& Maíz, 2013; Kelly \& Bruen, 2014) and works from both language and translation teaching fields that maintain that 'it is impossible to learn a language without comparing it to one's mother tongue' (Leonardi, 2011, p. 19), a translation task is presented as one of the various possible illustrations of that beneficial interlingual relationship. It is assumed that languages in contact exert an influence on each other (Krashen, 1981) and that this relationship inevitably generates an interaction between both languages that usually ends up in one language having a pervasive and detrimental influence on the other. Therefore, the operational part of the study examines the effect of that cross-linguistic interference of L1 into the L2 on a specific aspect, the analysis of calque errors (Odlin, 1993).These calque errors are classified and tagged following the typology proposed by Braga and Domínguez (2010). Considering errors to be a chance for improvement and a source of information, theresearch question tested here is whether the identification of negative language interferences of L1 in L2, concretely of calque errors, when doing inverse translations may contribute to raise cross-linguistic awareness (Cummins, 2007, p. 229) and so contribute to the avoidance of committing those errors in the future.

More precisely, this study analyses and discusses how this realization can alert students and teach them a lesson in order to not commit the same calque errors recurrently. According to the above-mentioned categorization, calque errors observed are tagged and their evolution in number and type is analyzed to check whether the research question is fulfilled. The results obtained will contribute to model future preventive measures to be adopted in the subjects' curriculum.

\section{Literature Review}

In the first place, it is necessary to take a look back to trace the usage of translation in FLT and the evolution of some FLT methods in the past. Next, a brief summary of the recent reconceptualization of translation as a teaching tool is presented. After that, the concept of task and its possibilities are outlined in order to specify and describe the type of task here undergone. Finally, the translation-based task here analyzed entails comparing a TT and an OT to detect undesired interferences from source into target language. Focusing on calque errors, an error analysis of types, distribution and evolution is made and presented and conclusions are drawn.

\subsection{Translation in the Past}

During the late $19^{\text {th }}$ and beginning of the $20^{\text {th }}$ century, the Grammar-Translation $(G T)$ methodology boomed for a few decades. It was mainly focused on learning grammar rules and isolated vocabulary by translating sentences from L2 into L1, quiet often, as its detractors point out (Cummins, 2006, p. 5), in a rather unnatural and decontextualized fashion. It came as no surprise when it was soon discredited as a methodology for FLT, although its supporters claimed that it was misunderstood and misused. The subsequent advents of the Direct or Natural method firstly and of the Communicative Approach, later, were happily welcomed. The Direct Method leant on two basics tenets: i) language used in class should emulate real life performances to recreate a natural speaking atmosphere; ii) this natural flow of sentences must be sequenced and intertwined and not produced in isolation. It proposes an immersion of the student in a foreign speaking environment, implicitly assuming that target language should be used exclusively for educational purposes and no recourse should be made to the 
mother tongue language (Cummins, 2007, p. 221). Consequently, this approach leaves no room for implementing activities that involve using the pupils' mother tongue (such is the case of translation). As a result, most modern FLT course books for L2 are exclusively based on L2.

After came the Communicative Approach, born from the socio and functional linguistics quite popular in the 60s and $70 \mathrm{~s}$. It considered language as a means for the expression of values and judgements, highlighting the communicative dimension of language over its grammatical features (Celce-Murcia, 2008, p. 44). Hence, the Communicative language teaching (CLT) approach emphasizes the functional component of language whereby language has to be studied in a contextualized way. Although it is widely admitted that FLT has not reached a consensus on what is the perfect teaching-learning methodology, there seems to be widespread agreement within the teachers of English as a Foreign Language (EFL) community that special worth can be bestowed on the Communicative Approach (Martínez, 2012, p. 290) inasmuch as, nowadays, communicative teaching principles are widespread in foreign language instruction worldwide. Most communicative method advocates firmly believe that using L1 when acquiring a foreign language is counter-productive and thus the use of translation is considered a hurdle in this context (Carreres, 2006, p. 1).

Nonetheless, recent FLT methodologies have gone a step forward by considering language something other than a mere communication tool and taking into account other cognitive factors related to contextual elements and personal experiences that affect learners' knowledge construction (Bransford, Brown, \& Cocking, 2000; Cummins, 2007). This new post-communicative paradigm in language teaching, commonly known as Constructivism, regards learners as active participants in sense-making processes, moving from previous experiences to build upon new information. So, under this methodology, meaningful contents dealing with authentic materials to which students can add their personal experiences and knowledge seem to foster effective learning.

\subsection{Revising Translation as a Didactic Resource in a FLT Class}

The topic dealt with in this paper falls into the long-standing debate between those in favor of exclusively using L2 in a FLT class and those in favor of giving allowance to resorting to L1 when necessary, (Cook, 2001; Thurnbull, 2001 in Cummins, 2007, p. 223). While nowadays the use of L1 is no longer considered as intrinsically detrimental to the Foreign Language class, there still remains an evident animosity towards its use. One of the possible applications of L1 in the FLT class is translation. As a teaching resource it rocketed for some time, only to plummet into discredit afterwards, and is at present being re-considered. Although many current teaching and learning policies worldwide are basically ruled by the monolingual instructional approach, some researchers allege that there is a dearth of empirical evidence backing this thesis (Cummins, 2007, p. 222) and that it is not consistent with how people naturally learn foreign languages (Bransford, Brown, \& Cocking, 2000). Cummins (2001) advises that due to the scarcity of experimental support for monolingual-only-teaching approaches, some studies have focused on the ideological assumptions underlying this view. Amongst the most cited assumptions related to teaching English as a Foreign Language lies the claim that it is best taught in English, which excludes translation activities from foreign language classes (Cummins, 2007, p. 227).

However, the view on translation as an instructional method in a FLT class has been reverted and there are voices that assert its relevance and highlight its valuable influence to improve L2 skills by facilitating lexis acquisition, developing writing style and promoting comprehension of how languages in contact work (Schaffner, 1998; Malmkjær, 1998). One of the possible applications of translation tasks in FLT classes is to promote the learning and retention of second language vocabulary and the construction of grammatical structures (Enríquez, 2003 , p. 120). In fact, translation has lately been gaining ample ground in various fields. As Malmkjær (1998, p. 1) puts it, there have been 'significant and visible signs of a revival of translation in language teaching according to recent literature and applied linguistics'. In this line, Machida (2008, p. 143) affirms that translation creates more opportunities for learners to focus not only on meaning, but also on the form of the text, and that poses challenging projects that involve linguistic, cultural and pragmatic knowledge.

Actually, some current views consider translation to be an activity that bridges the gap between two languages when there is an uneven level of linguistic, conceptual, and background knowledge development. Mother tongue linguistic and cultural competence is quite often a good way ahead of L2 in L2 students. Therefore, L2 competence needs to be further developed to catch up with L1 as much as possible. At the same time, translation provides opportunities for the students to learn about foreign linguistic issues, while also building upon their cultural knowledge. As Leonardi (2011, pp. 62-63) affirms: 'L1 and L2 are constantly and automatically interwoven in the learner's mind at all levels, such as phonology, syntax, lexis and pragmatics.' So, a functional approach to translation is embraced, based on the Skopos theory (Vermeer, 1996). This theory uses the Greek 
term 'Skopos' that means 'purpose/aim' to encapsulate its philosophy: 'The Skopos of a particular translation project may require either a free or a faithful translation, or anything in between [...] depending on the purpose of the translation' (Nord, 1997, p. 29). Accordingly, this view of translation highlights the communicative function of language and is inextricably linked to a communicative purpose that the translation must fulfill in the target language. In this sense, a translation may be called functional when it achieves its intended purpose and that functionality not only depends on linguistic factors inherent to the text, but also on contextual-situational features (Nord, 2006, p. 31).

Interestingly enough, according to the findings of the First European Survey of Language Competences (2011) (Note 1), a comparative study of fifteen European countries/regions on their English level attainment provides some noteworthy data. Spain scores fourth-last in reading, second-last in listening, and fourth-last in writing. These poor results reflect the information collected on the foreign language proficiency of students in the last year of lower secondary education or the second year of upper secondary education. These results are linked to the fact that Spain scored second-last in using translation in language classes. Conversely, those low performances gathered in Spain contrast with the fact that Finland, the European country in this study that scores best in English proficiency, also scores first in using the translation-related tasks of various kinds in their FLC. Hence, this piece of data on its own should spark the curiosity and necessity to reassess the concept of translation in EFL classes in Spain and to test it. What is more, the Directorate General for Translation of the European Commission has recently published the findings of a research project carried out from September 2012 to June 2013, which delves into the role of translation in language teaching in the European Union (Note 2). The project outcomes were drafted in a report that poses some appealing research questions. The first one is 'Can translation contribute to effective language learning?' (EC, 2013, p. 5). Thus, that question has become a topical issue.

Bearing these facts in mind and believing that translation based activities can create ideal learning opportunities with positive L1 use in SL/FL learning (Machida, 2011, p. 740), this paper describes a real experience that departed from the same research question as the EU research project (EC, 2013, p. 5) and that has been implemented in a particular university settingto assess its results and with the intent to evaluate the feasibility of inserting translation activities into FLT class curriculum.

\subsection{Defining Task}

The experience here described is based on a task: a translation assignment. One of the most widespread and generally accepted academic definitions of a task is that of Nunan (2006):

'A task is a piece of classroom work that involves learners in comprehending, manipulating, producing or interacting in the target language while their attention is focused on mobilizing their grammatical knowledge in order to express meaning, and in which the intention is to convey meaning rather than to manipulate form.'

Nonetheless, as Bygate, Skehan and Swain (2001, p. 11) aptly point out in this regard, 'definitions of task will need to differ according to the purposes for which the tasks are used.'For some, a task is defined as 'a piece of work undertaken for oneself or for others, freely or for some reward' (Long, 1985, p. 89). From a pedagogical viewpoint, Ellis (2003, p. 16) states that a task is 'a work plan that requires learners to process language pragmatically in order to achieve an outcome that can be evaluated in terms of whether the correct or appropriate propositional content has been conveyed'. Simultaneously, it is worth noting that task-based methodologies favour an active and flexible approach to teaching languages and translation since they focus on pragmatics. Their aim is communicative; the tasks try to reproduce real life situations and thus they bring classroom activities closer to professional practice. In this vein, despite the fact that the translation task here deployed was merely pedagogical for the students, the final usage of the translated text was professional. Consequently, it has undergone a typical process of a professional translation assignment (Nord, 1997). Besides, this task-based approach by means of a pedagogical translation methodology reinforces the student-centeredness (Leonardi, 2011, p. 86) and compels students to play a central role in their learning process, quite in tune with the principles of the European Higher Education Area (EHEA) framework.

According to Duff (1994), properly designed translation tasks can be employed to improve foreign language skills and to develop three qualities essential to all language learning: accuracy, clarity and flexibility. Considered as such, the ultimate goal of this type of translation task is not to train professional translators, but to contribute to the enhancement of learners' knowledge in the English language. In other words, the aim of the translation task here is not to teach translation itself, but to teach foreign language skills by means of translation (Duff, 1989, p. 3).

Designing a task for pedagogical purposes requires the consideration of several factors. Some of these are the aim of the task, the time allotted, the level of difficulty, the profile and the role of the learners, and the function 
of the teacher, to cite but a few. Factors involved are described below in the Procedure section (2.1).

Under the form of task-based approach (TBT), a reconceptualized translation activity is used with Foreign Language English as L2 studentsto study the cross-linguistic interference aroused between L1 and L2. Posing these two notions together and using translation as a task, language learners are given with the chance to deal with challenging, purposeful, meaningful assignments equivalent to real-world activities.

\subsection{Linguistic Interference}

During the last few decades, the role of cross-linguistic influence (CLI), mainly in second language acquisition (SLA), has been a field of ample research (Larsen-Freeman \& Long, 1991; Odlin, 1989; James, 1998), especially in relation to CLIL (Content and Language Integrated Learning) (Dafouz, 2009; Lasagabaster \& Ruiz de Zarobe, 2010). Odlin (1993, p. 27) states that whenever there is language transfer across two languages (and cultures), there is an "influence resulting from similarities and differences between the target language and any other language that has been previously (and perhaps imperfectly) acquired". It is commonly accepted that the influence exerted by the mother tongue in the acquisition of a second language (L2) may have two opposite effects (Krashen, 1981): advantageous (positive transfer) and pernicious (negative transfer). In order to find out what effect this transfer has, learners' mother tongue and the target language have to be compared to observe errors made in order to perform an Error Analysis (Heydari \& Bagheri, 2012, p. 1583). This procedure consists of identifying and describing errors found in order to trace their origin and propose solutions.

Regarding error notion from the functional perspective of translation here embraced, the errors are defined not in formal terms of correct and incorrect, but instead in pragmatic terms of adequate or inadequate regarding the function to be fulfilled by the text and the target reader (Nord, 1997, p. 35). One of the most common instances of negative linguistic transfers is the incorrect realization in L2 attributed to the influence of certain features existing in the native language (Carrió-Pastor y Mestre-Mestre, 2014, p. 103). This undesired interference is usually known as 'calque', which Odlin (1993, p. 37) defines as an 'error that reflects very closely a native language structure'. That negative transfer, which is mostly caused by an insufficient mastery of L2 that pushes the student to resort to his mother tongue structures, brings about calque errors. According to Odlin (1993), those errors can be classified into four types: i) underproduction errors, due to an omission in L2 under the influence of L1; ii) overproduction errors, due to an addition of some elements from L1 into L2 under the influence of the mother tongue; iii) misinterpretation errors, due to the intermingling of L1 and L2 that may provoke misinterpretations and, iv) production errors, that are classified into two subtypes: substitutions (usage of L1 elements in L2) and calques. The latter subtype is precisely the one with which this paper is concerned.

\subsection{Calque Errors}

This study focuses on errors provoked by calques made by Spanish learners of English as a second language when writing (inverse translation) in L2. The systematic analysis of errors allows for collecting, identifying, describing and explaining the causes, as well as for evaluating errors committed by a L1 speaker by comparison withinthe target language (Corder, 1974). Besides, apart from being extremely prolific in the analysis of second language acquisition, errors in the target language represent an excellent opportunity for improvement (Carrió-Pastor, 2004). Undoubtedly, a deep understanding of what is the rationale that provokes the negative transfer of errors committed when writing by foreign language students will both help the teacher to know the students' particular difficulties in their learning process (Heydari \& Bagheri, 2012, p. 1584) and will raise students' consciousness of their own mistakes so that they might build upon them.

In regard to error taxonomies, much has been debated, but not one final classification is universally recognized. Thus, we highlight one of the basic and most influential classifications of linguistic errors that distinguishes between two main categories: Interlingual and Intralingual (Larseen Freeman \& Long, 1991, p. 58). Intralingual errors are caused by L1 interference on L2 production and Interlingual errors are due to inadequacies in L1. Bearing that in mind, and for the empirical analysis of the data gathered in this translation experience, the typology of calque errors put forward by Braga and Domínguez (2010, p. 116) will be employed. Drawing on previous works by López Minett (1999) and Rodríguez (1999), Braga and Domínguez (2010, p. 118), calque errors are classified into three main categories:

1) Morphological calques,

2) Syntactic calques and

3) Lexical calques.

Morphological calques cover eight types of calques, all dealing with interferences regarding word structures. As for the syntactic calques, only two types are included in this taxonomy. A first subtype of structural calques 
focuses on sentence links and refers to that missing part of a sentence that breaks its internal cohesion. The second syntactical error, word order, alludes to the correct positioning of elements within a clause. Lexical calques, the third type in the classification, have been extensively addressed throughout history and thus various proposals have been put forward. For the purposes of this study and following Haugen's proposal (1953) included in that of Braga and Domínguez (2010, p. 126), two broad subcategories are distinguished. In the first place, the lexical loans, which consist of a lexical enlargement of a lexical unit, and in the second place, the lexical creations, which add new meanings to that of the original. Hence, the classification of errors utilized by Braga and Domínguez (2010, p. 118) that will serve as the basis for the analysis is depicted in the following table:

Table 1. Calque categorization (Braga \& Domínguez, 2010, pp. 118-127)

\begin{tabular}{lll}
\hline Morphological & Syntactic & Lexical \\
\hline Article (MCa) & Sentence link (SCsl) & Extensions (LCe) \\
Adjectives (MCad) & Word order (SCwo) & Creations (LCc) \\
Adverbs (MCadv) & & \\
Nouns (MCn) & & \\
Verbal tenses (MCvt) & & \\
Pronouns (MCp) & & \\
Prepositions (MCpp) & & \\
\hline
\end{tabular}

The identification tagging of calque errors according to the classification put forward by Braga and Domínguez (2010, p. 120) will reveal which is the most common calque error type and serve to detect student's learning needs and teaching weaknesses.

\section{Method}

This pilot study has been conducted at the University of Castilla-La Mancha (UCLM), Spain. The purpose of this limited-scale research is to get a clearer idea of how translation based tasks can contribute to improve English skills, focused on calque errors committed when writing in L2. Under an external internship agreement between the faculty of Social Sciences and Humanities of the University of Castilla-La Mancha (Cuenca campus) and a renowned nearby Archeological Park, the task solicited was to undergo a translation assignment (Nord, 1997). The main terms of the internship agreement set a semester long deadline to deliver the translation assignment and required that the participants be UCLM students from the Social Sciences and Humanities faculty.

The project consisted of carrying out an inverse translation (into an L2) of the Archeological Park's audio guide. Written in Spanish, the c. 24000-word original text had to be translated into English. The high concentration of specialized lexical units, the compact syntactic structures and the abundance of nominalizations made the text at hand easily recognizable as a scientific, technical or specialized (Note 3) text. The text's purpose was informative and it was aimed to be voiced-over in the audio guide of the Archeological Park. For that purpose, the voluntary collaboration of students enrolled in the advanced level English subject (English III (Note 4)) was requested. All of the students signed up for the subject showed great interest and willingness to take part in this innovativeproject. Nonetheless, due to the difficulty of the given task, the students were shortlisted. The candidates were chosen according to the 'best mark' criteria amongst those marks obtained in the preceding semester's FLC. The expected language mastery of this group was intermediate (B1, 'Threshold' according to CFER), although some differences in attainment were found amongst them, as evidenced by their marks. Only those students who attained a minimum of B1 were eligible. Amongst those who wished participate (a total population of thirty-three), sixteen students were chosen, which accounted for approximately half of the class. The group was comprised of the twelve girls and four boys with the best marks in the English subject, who were on their way to achieving an upper-intermediate level (B2, Vantage according to CFER). None of them had had any previous contact with translation, neither pedagogical nor professional. The length of the text to be translated and time constraints (time availability of students) made it necessary to divide the translation assignment into two halves and to form two groups of learner-translators (here forth Group A and Group B) that could work simultaneously on their part. Thus, the translation job could progress steadily and at double speed. The groups were made evenly by taking into account the FLC grades. Each group had three students with A grades and five 
with B grades. Besides, considering the sex variable, two boys and six girls composed each group.

\subsection{Procedure}

Due to the fact that the chosen students had never received any formal instruction on translation, the first two weeks were devoted to giving them a crash course on the basics of translation, presenting them with the phases of the translation process and making them aware of the fact that, as any other industrial process, it is subject to considerations of time and effort (Sager, 1989, p. 91) and that decisions must be made paying heed to those two facts. Several models for the translation process were presented, including that of Mossop (2001, p. 40), which entails three phases (pre-drafting, drafting and post-drafting) and five activities (analyzing ST, drafting TT, terminology research, checking draft and verifying translation assignment requirements) or tasks, here understood as the work to be done by the translator to produce the final translated text. Another model was that of Machida (2011, pp. 742-743), who states that the translator has a) to comprehend the original text, b) to search for the equivalent expressions in the target language, and then c) to synthesize them to recapture the meaning of the original text in the target text.

As for translation methods, procedures and strategies, an assortment of the most commonly used ones were presented and exemplified following Newmark's classification (1999, pp. 117-132), which includes loans, naturalizations, cultural equivalents, functional equivalents, descriptive equivalents, synonymy, through translation, shifts, modulations, canonical translations, paraphrasing, etc.

Once the whole groupwas introduced to the nuts and bolts of translation, the sixteen students were divided into the two groups above mentioned to work collaboratively on their assignments. Since the original Spanish text was distributed into 18 Tracks, the text was divided into two proportionate halves. Group A took care of tracks 0-8 and group B of tracks 9-17.

On a weekly basis during the remainder of the term, the students' commission was to carry out the translation assignment on a semi-guided basis. Two days per week each group would come to the English Language officeto hand inthe draft translation made so far. These sessions were used to receive feedback, exchange opinions, and to share and clarify doubts on previously delivered draft translations. Following this procedure, the work progressed. The tutors' work consisted ofcorrecting the draft translations by comparing each sentence, one by one, from the original to that of the students' translation. This bilingual revision (Mossop, 2001, p. 67) allowed for the identifying and tagging of calque errors according to the above-mentioned Calque categorization (Table 1). A thorough proofreading and several revisions of each track were needed to lick the translation into shape and arrive at its final version. At the end of the task, a feedback session was held with each group of participants to gather their opinions on the usefulness and profitability of carrying out translation tasks in FLT class.

\section{Results}

The analysis of calque errors identified has shed some light on the most frequent calque types and on their distribution along the timeline of the project, contributing so to draw conclusions accordingly.

\subsection{Error Tagging and Distribution}

The global number of errors identified in the assignment was 816. The distribution according to the categorization set out above (Figure 1) positions Morphological calques as the most common type of calques (n $=456)$, followed by Syntactical calques $(\mathrm{n}=216)$ and, in the last place, by Lexical calques $(\mathrm{n}=144)$. Graphically, these statistics are so represented:

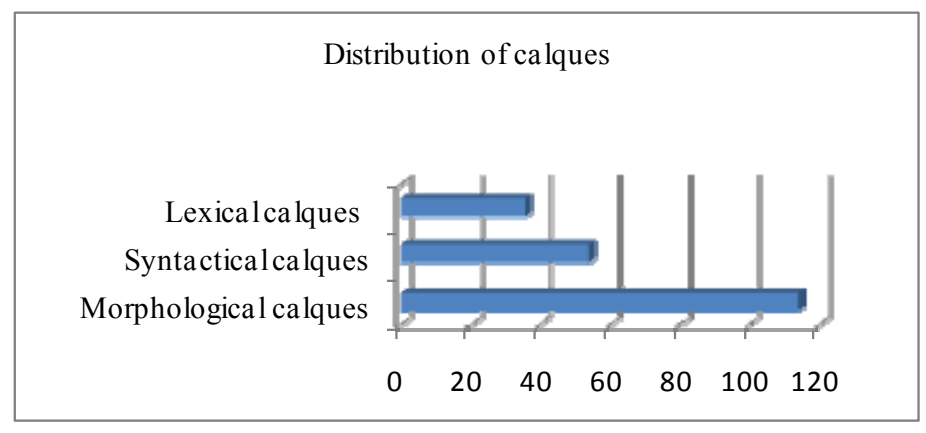

Figure 1. Distribution of calques per broad type 
Therefore, despite the fact that the text herein analyzed is of a specialized nature and contrary to previous expectations that would place lexical calques first, they score last in calque distribution $(n=144$ calques, $17.64 \%$ ), whereas morphological calques score first with 456 calques (55.88\%) and syntactical calques rank second (26.47\%). In Figure 1, we notedthat while (specialized) lexis concentration is a distinguishing feature of specialized texts, it is not always the main hurdle when translating specialized content. On some occasions, the more specialized the lexis is, the easier it is for a translator to find a lexical unit with specialized meaning that 'functions' in the foreign language. In this case, students' previous knowledge on the topic and their familiarity with the expert vocabulary of the field (due to their academic knowledge) definitely helped them to better deal with the lexical issues than with the syntactical ones. Nonetheless, a closer look at the three macro categories involves breaking them down into their subcategories for a more detailed analysis.

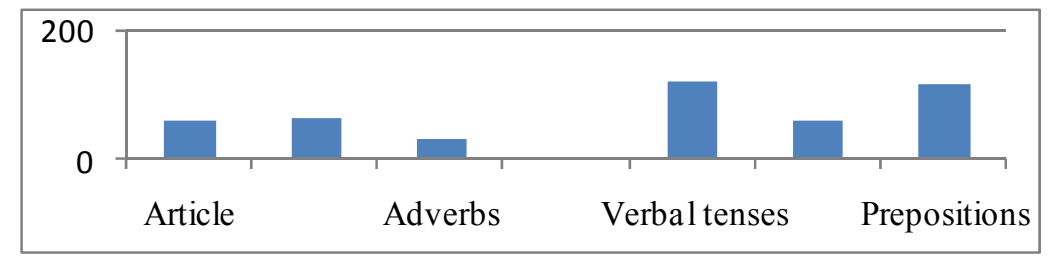

Figure 2. Distribution of morphological calques

Within the morphological calques, as Figure 2 above shows, the two highest ranked items are verbal tenses calques (MCvt) with 120 errors $(26.31 \%)$ and preposition calques (MCpp) with 116 errors $(25.43 \%)$. Next, adjectives come with 64 errors $(14.03 \%)$ and then both articles and pronouns follow with 60 errors (13.15\%) each. Finally, the two lowest rankings are found in adverb errors with $32(7.01 \%)$ and noun errors with only 4 $(0.87 \%)$.

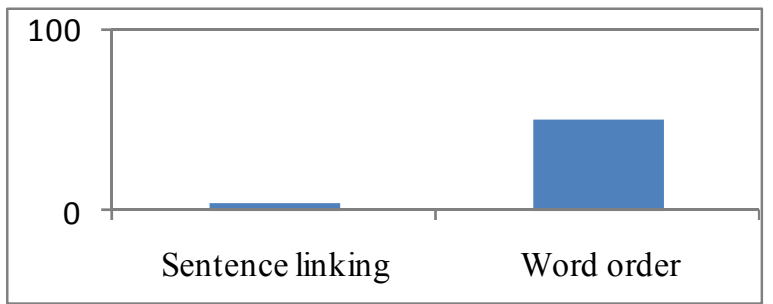

Figure 3. Distribution of syntactical calques

Figure 3 shows a striking difference between the two subcategories of Syntactical calques. By far, word order with 200 calques $(92.59 \%)$ is the top ranked calque within this category, followed by sentence linkingwith 16 calques (7.41\%), which is the least frequent. Besides, it is remarkable to note that word order calques also scored first in the overall classification, representing $24.5 \%$ of the total figure. Although it is not recommended to make extensive use of the passive voice in formal written English, the fact is that passives are repeatedly found in both spoken and written English and are far more common in English than in Spanish. Nevertheless, this subject object inversion - has not been properly understood as can be seen in the example: “...where were carried out theatrical performances" (inappropriate subject-verb placement in the sentence).

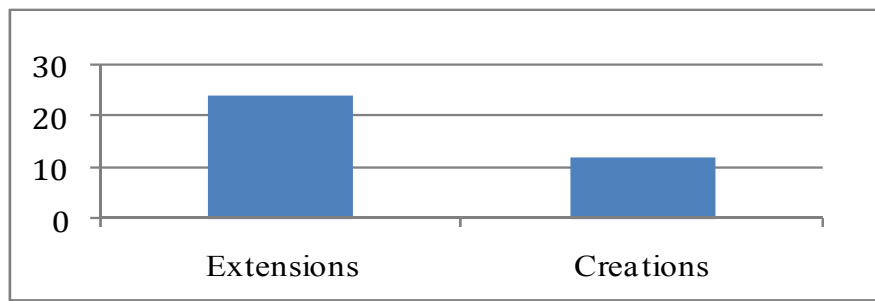

Figure 4. Distribution of lexical calques 
Incorrect extensions of existing meanings are employed in 96 calques $(66.66 \%)$, whereas inappropriate creations of new meanings are found in 48 lexical calques (33.34\%). Extensions double creations in number of appearances, as Figure 4 above shows, whichindicatesthat students make frequent use of existing terms incorrectly by amplifying their meaning content.

Next, an array of examples extracted from the translation and the original that try to illustrate each of the three broad categories of calques (and subcategories) are listed below.

To begin with, morphological calques are categorized into eight subtypes that are broken downbelow.

Table 2. Example of Morphological error caused by an article calque (MCa)

\begin{tabular}{|c|c|c|}
\hline OT & TTdraft-Article (MCa) & TT-Final version \\
\hline $\begin{array}{l}\ldots \text { destinadas al baño e higiene, al } \\
\text { esparcimiento y a los negocios de } \\
\text { los habitantes de la ciudad }\end{array}$ & $\begin{array}{l}\text { They were used for bath, } \\
\text { hygiene, the relaxation ... }\end{array}$ & $\begin{array}{l}\text { They were used for bath, } \\
\text { hygiene, } \varnothing \text { relaxation ... }\end{array}$ \\
\hline $\begin{array}{l}\text { El emplazamiento de la estatua del } \\
\text { emperador de Roma. }\end{array}$ & $\begin{array}{l}\text { The location of the statue of the } \\
\text { emperor of Rome. }\end{array}$ & $\begin{array}{l}\text { The location of the statue of } \\
\text { Rome's emperor. }\end{array}$ \\
\hline
\end{tabular}

It came as no surprise to find a recurrent overutilization of the definite article 'the' in the English translation, due to the misleading influence of its frequent appearance in Spanish syntactical constructions. Similarly, an overuse of the preposition of, in resemblance to Spanish grammar, resulted in excessive repetition in the second example. Therefore, it was advisable to lighten the repetition by using a Saxon genitive.

Table 3. Examples of Morphological errors caused by an adjectivecalque (MCad)

\begin{tabular}{llll}
\hline OT & TT draft-Adjective (MCad) & TT-Final version \\
\hline Es de planta casi semicircular y & This almost semicircular floor was & Its almost semicircular floor \\
rodeada de tres amplias gradas & surrounded by three extensive & was surrounded by three ample \\
reservadas para los asientos de las & steps reserved for authorities and & $\begin{array}{l}\text { stands reserved for authorities } \\
\text { and distinguished personalities. }\end{array}$ \\
autoridades y personajes destacados. & noticeable personalities ... & and
\end{tabular}

The incorrect choice of adjectives in the TT could possibly be due to an excessive closeness to that of the original text that led the students to use adjectives in the TT that resemble those of the original. The qualifier 'Extensive' (English) resembles 'extenso' in Spanish and 'noticeable' is similar to the Spanish adjective 'notable', an adjective that in Spanish usually collocates with 'personalities'.

Table 4. Examples of Morphological errors caused by an adverb calque (MCadv)

\begin{tabular}{lll}
\hline OT & TT draft-Adverb (MCadv) & TT-Final version \\
\hline $\begin{array}{l}\text { Una estaba orientada hacia el este y } \\
\text { la otra hacia el oeste. }\end{array}$ & $\begin{array}{l}\text { One was facing to the East and the } \\
\text { another to the West. }\end{array}$ & $\begin{array}{l}\text { One was facing to the East and the } \\
\text { other to the West. }\end{array}$ \\
\hline $\begin{array}{l}\text { Para su emplazamiento se eligió una } \\
\text { ubicación bien situada en el centro } \\
\text { de la ciudad con acceso directo desde }\end{array}$ & $\begin{array}{l}\text { For its emplacement was chosen a } \\
\text { good-located place in the heart of }\end{array}$ & $\begin{array}{l}\text { For its location was chosen a } \\
\text { el kardomaxituated place in the heart of } \\
\text { the cith direct access from the }\end{array}$ \\
$\begin{array}{ll}\text { kardomaximo through a big stair } \\
\text { the with direct access from the }\end{array}$ & kardomaximo through a big stair \\
\hline
\end{tabular}

The first example of adverb error calques, produced by a misuse of 'another', has long been noticed both in written and in oral productions in the FLT class. The second example, 'good-located', is another recurrent mistake deeply rooted in Spanish speakers of English who tend to use the adjective instead of the adverb required by the syntactical construction. 
Table 5. Examples of Morphological errors caused by a noun calque (MCn)

\begin{tabular}{|c|c|c|}
\hline OT & TT draft-Noun (MCn) & TT-Final version \\
\hline $\begin{array}{l}\text { Los músicos de la orchesta estaban } \\
\text { situados ... }\end{array}$ & $\begin{array}{l}\text { The musicans of the orchestra } \\
\text { were placed... }\end{array}$ & $\begin{array}{l}\text { The musicians of the orchestra } \\
\text { were placed... }\end{array}$ \\
\hline $\begin{array}{l}\text { Para su emplazamiento se eligió una } \\
\text { ubicaciónbien situada en el centro de } \\
\text { la ciudad con acceso directo desde el } \\
\text { kardomaximopor unas escaleras }\end{array}$ & $\begin{array}{l}\text { For its emplacement was chosen a } \\
\text { good-located place in the heart of } \\
\text { the city with direct access from the } \\
\text { kardomaximo through a big stair }\end{array}$ & $\begin{array}{l}\text { For its location was chosen a } \\
\text { well-situatedplace in the heart of } \\
\text { the city with direct access from the } \\
\text { kardomaximo through a big stair }\end{array}$ \\
\hline
\end{tabular}

Once again, the resemblance of the noun ('musican' and 'emplacement') to those in Spanish ('músico' and 'emplazamiento') misled the student-translation into those calque errors. In the first case, the noun calque derives into a spelling mistake and, in the second, it provokes an incorrect semantic use of the noun. 'Emplacement' refers to a structure on or in which something is firmly placed, usually in relation with a gun or other weapon or to the process or state of setting something in place or being set in place (Note 5).

Table 6. Examples of Morphological errors caused by a verb tense calque (MCvt)

\begin{tabular}{lll}
\hline OT & TT draft-Verb tense (MCvt) & TT-Final version \\
\hline $\begin{array}{l}\text { En la actualidad se ha convertido } \\
\text { en un parque arqueológico para el } \\
\text { disfrute de los visitantes. }\end{array}$ & $\begin{array}{l}\text { Nowadays it has being turned into an } \\
\text { Archeological park for visitors' } \\
\text { enjoyment. }\end{array}$ & $\begin{array}{l}\text { Nowadays it has been turned } \\
\text { into an Archeological park } \\
\text { for visitors' enjoyment. }\end{array}$ \\
\hline $\begin{array}{l}\text { Al atravesarla, nos encontraremos } \\
\text { con un gran conjunto de } \\
\text { construcciones monumentales.... }\end{array}$ & $\begin{array}{l}\text { When we going through it, we will } \\
\text { constructions... }\end{array}$ & $\begin{array}{l}\text { When we go through it, we } \\
\text { find a big collection of } \\
\text { monumental constructions ... }\end{array}$ \\
\hline
\end{tabular}

Two different causes may explain the verb tense calques found in the two examples above. We feel inclined to believe that the first ('being' for 'been') calque could probably be attributed to their phonetic similarity. The second verb tense calque is surely caused by the direct transfer of Spanish verb tenses into English. Nevertheless, that exact copy of verb tenses breaks the internal verbal cohesion relations ('going' and 'will find')

Table 7. Examples of Morphological errors caused by a pronoun calque (MCp)

\begin{tabular}{lll}
\hline OT & TT draft-pronoun (MCp) & TT-Final version \\
\hline $\begin{array}{l}\text { Fue utilizado como archivo de la } \\
\text { ciudad, cuya entrada se realizó }\end{array}$ & $\begin{array}{l}\text { It was the city's archive what } \\
\text { entrance... }\end{array}$ & $\begin{array}{l}\text { It was the city's archive } \\
\text { whose entrance.... }\end{array}$ \\
\hline $\begin{array}{l}\text { Fue construído al mismo tiempo } \\
\text { que el foro. }\end{array}$ & $\begin{array}{l}\text { It was built at the same time that the } \\
\text { forum }\end{array}$ & $\begin{array}{l}\text { It was built at the same time } \\
\text { as the forum }\end{array}$ \\
\hline
\end{tabular}

In the first instance, the relative pronoun with possessive value ('cuya') has been translated to the English relative pronoun 'what', which can be a pronoun or a possessive determiner. This latter option could have led the student-translator to mistake it for the pronoun that indicates possession, 'whose'.

Table 8. Examples of Morphological errors caused by a preposition calque (MCpp)

\begin{tabular}{lll}
\hline OT & TT draft - preposition (MCpp) & TT - Final version \\
\hline $\begin{array}{l}\text { Para adecuarse a una ciudad } \\
\text { romana, hubo que recurrir a } \\
\text { explanaciones y aterrazamientos, ... }\end{array}$ & For adapt it to a Roman city... & $\begin{array}{l}\text { In order to adapt it to a Roman } \\
\text { city, terracing and land levelling } \\
\text { works were carried out, ... }\end{array}$ \\
\hline Frente a ella se alza la escena ... & $\begin{array}{l}\text { Opposite the floor, the stage is } \\
\text { raised ... }\end{array}$ & $\begin{array}{l}\text { Opposite to the floor, the stage is } \\
\text { raised ... }\end{array}$ \\
\hline
\end{tabular}


In the first instance, the preposition 'for', with a purposeful meaning, is here wrongly used since it cannot accompany a present verb tense and an object should follow it. Instead, the transitional phrase 'in order to' that conveys purpose should be used. The second example requires the preposition 'to' as a complement of the place preposition 'opposite', which was possibly omitted because the Spanish equivalent 'frente a' has no preposition.

Table 9. Examples of Syntactical errors caused by a sentence link (SCsl)

\begin{tabular}{lll}
\hline OT & TT draft-sentence link (SCsl) & TT-Final version \\
\hline $\begin{array}{l}\text { Originalmente, fue un colector } \\
\text { de aguas múltiple. }\end{array}$ & $\begin{array}{l}\text { Originally, } \boldsymbol{\varnothing} \text { was a multiple water } \\
\text { collector. }\end{array}$ & $\begin{array}{l}\text { Originally, it was a multiple water } \\
\text { collector. }\end{array}$ \\
\hline $\begin{array}{l}\text { Tras la conquista romana se } \\
\text { convirtió en una ciudad celtíbera }\end{array}$ & $\begin{array}{l}\text { After the Roman conquest, Øturned } \\
\text { into a Celtiberian city. }\end{array}$ & $\begin{array}{l}\text { After the Roman conquest, } \underline{\text { the }} \\
\text { city/it turned into a Celtiberian city. }\end{array}$ \\
\hline
\end{tabular}

Regarding the sentence link, both examples in Table 9 show a subject drop in the subordinate clause, resembling the Spanish patternquite closely.

Table 10. Examples of Syntactical errors caused by a wrong word order (SCwo)

\begin{tabular}{|c|c|c|}
\hline OT & TT draft-word order (SCwo) & TT-Final version \\
\hline $\begin{array}{l}\ldots \text { donde se representaban } \\
\text { actuaciones teatrales. }\end{array}$ & $\begin{array}{l}\ldots \text { where were carried out theatre } \\
\text { performances }\end{array}$ & $\begin{array}{l}\text {...where theatre performances } \\
\text { were carried out. }\end{array}$ \\
\hline tual del & $\begin{array}{l}\text {...to the present town of } \mathrm{XX} \\
\text { (name of town) location. }\end{array}$ & of XXXX (name). \\
\hline
\end{tabular}

Once again, the Spanish syntactical construction exerts a pernicious influence on the English output. The examples contained in Table 10 show how the correct order of the elements in the English version has been altered. In the first case, the SVO (Subject Verb Object) order has been changed to imitate the Spanish construction. In the second case, the noun has been wrongly postponed to the end of the sentence instead of placing it after the qualifier.

Table 11. Examples of Lexical errors caused by a lexical extension (LCle)

\begin{tabular}{|c|c|}
\hline OT & TT draft-lexical extension (LCle) TT-Final version \\
\hline $\begin{array}{l}\text { El paseo por las ruinas permite admirar } \\
\text { los edificios que se construyeron para } \\
\text { realizar espectáculos. }\end{array}$ & $\begin{array}{l}\text { The stroll along the ruins allows The stroll along the ruins allows } \\
\text { contemplating the buildings contemplating the buildings raised } \\
\text { raised for realizingof spectacles. for carrying out spectacles. }\end{array}$ \\
\hline $\begin{array}{l}\text { La ciudad fue siempre un importante } \\
\text { centro de comunicaciones para... }\end{array}$ & $\begin{array}{l}\text { The city was always an important } \text { The city was always an important } \\
\text { communication road for... } \\
\text { communication center for... }\end{array}$ \\
\hline
\end{tabular}

The Spanish similarity of the verb 'realizar' with the English 'realize' has led the student to use this false friend in this context. Instead, the phrasal 'to carry out' fits much better, due to the semantics. In the second extract, the student's choice ('road') does not quite reflect the sense of the original ('centro'). Thus, the election of the word 'center' matches more precisely the content of the Spanish original.

Table 12. Examples of Lexical errors caused by a lexical creation (LClc)

\begin{tabular}{|c|c|c|}
\hline OT & TT draft-lexical creation (LClc) & TT-Final version \\
\hline $\begin{array}{l}\text {... fueron necesarios sifones para } \\
\text { vencer algunos desniveles. }\end{array}$ & $\begin{array}{l}\text {.. siphons were necessaried to } \\
\text { overcome thehill unevenness. }\end{array}$ & $\begin{array}{l}\text { Siphons were needed to overcome } \\
\text { the hill unevenness. }\end{array}$ \\
\hline El cementerio se extiende hasta. & This cementery extants up to the. & This cemetery extends up to... \\
\hline
\end{tabular}


Once again, the English expression was swayed by the Spanish morphology and resulted in anungrammatical coinage ('necessary') that resembles that of the original text ('necesario') and is also similar to the correct past participle of the verb 'to need'. Likewise, it was the case of the Spanish verb 'extenderse' that led the student to invent a new verb ('extant'), something in-between the Spanish original and the correct English equivalent ('to extend') for this context.

Bearing in mind former classification of calque errors (Table 1), the revision of the translated text brought about a heterogeneous distribution of the number of calques per calque type and per track that are summarized in the following tables.

Figures 1, 2 and 3 above gather all the information related to the calques identified and tagged in the three broad categories and their corresponding subcategories. However, this data compilation allows for other, more illustrative graphical representations for the purposes of this study, such as the ones shown in Figures 4, 5, 6 and 7 below:

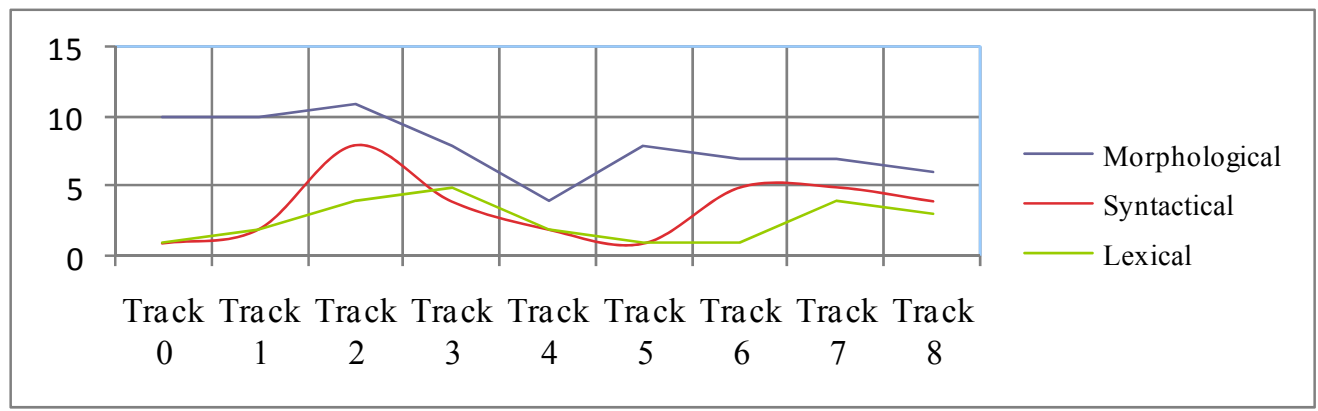

Figure 4. Distribution of calques produced by group A according to broad category and track (Tracks $0-8)$

The scores depicted in Figure 4 (lines) show the evolution in the total number of errors (calques) made by group A in each track (0-8) classified per broad category. Their behavior displays some differences. On the one hand, the progress in the number of morphological errors fluctuates but, in general terms, it trends downwards. On the other hand, syntactical and lexical calques wax and wane. They have their lowest values on the first two tracks (0-1) and their two highest on tracks 3 and 4, whereas on tracks 4-6 they register low values again, and they attain average scores on tracks 7 and 8 . Considered as a whole, the evolution in the number of calques committed by group A per track draws the line that it is shown in Figure 5 below.

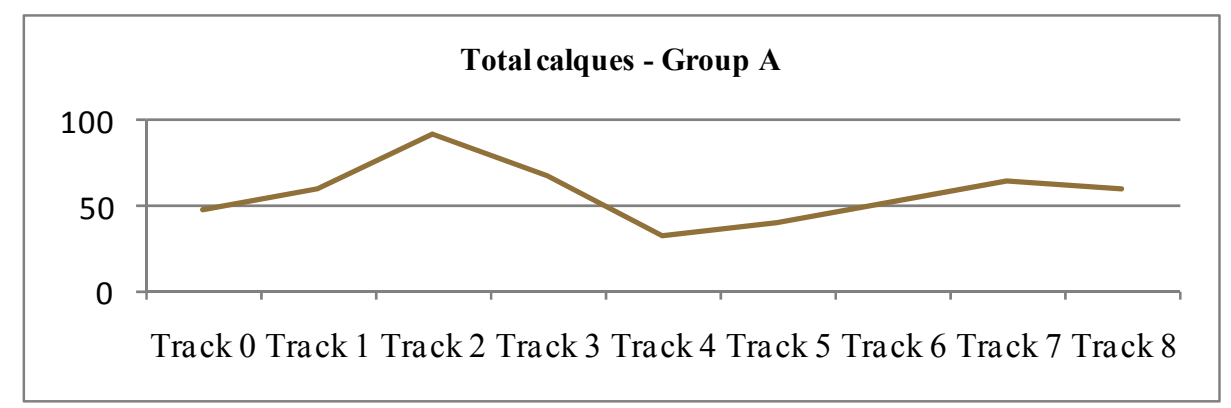

Figure 5. Number of calques produced by group A according to track (Tracks 0-8)

The mean value of errors made by this group per track is 57.3, with a maximum score of 92 errors on track 2 and a minimum of 32 on track 4. As Figure 5 shows, error values plummet from track 2 to 4 , lowering by 60 the number of calque errors. From there, error figures swing slightly up and down with no relevant modification. 


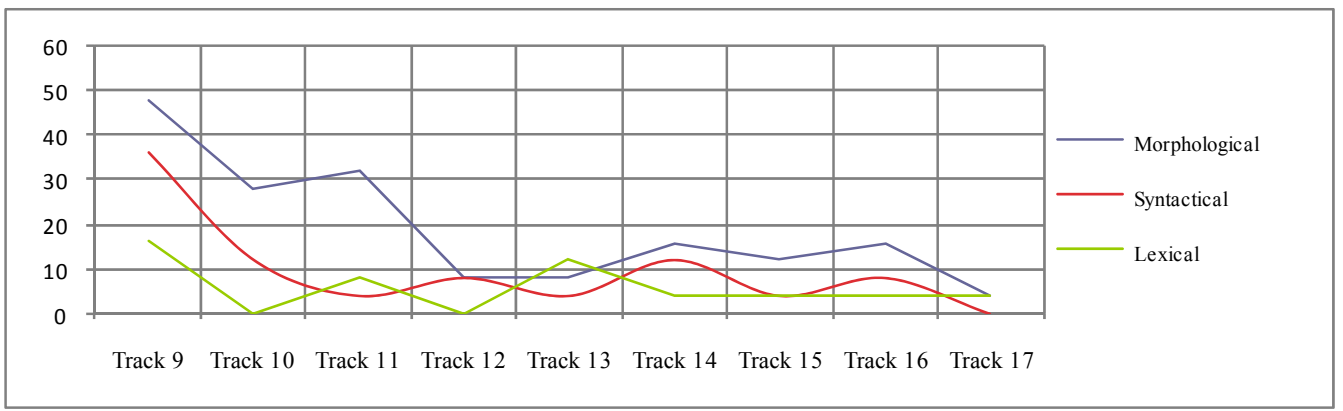

Figure 6. Distribution of calques produced by group B according to broad category and track (Tracks 9-17)

While the data in Figures 4 and 5 do not describe an unambiguous steady decrease tendency, the scores represented in Figure 6 leave no room for questioning their downward trend. A continuous drop in the number of calque errors found follows initial peaks in scores, reaching almost null values in the final track. Even more clearly, the representation of the mean value of calques per track depicts that falling trend, as shown in Figure 7.

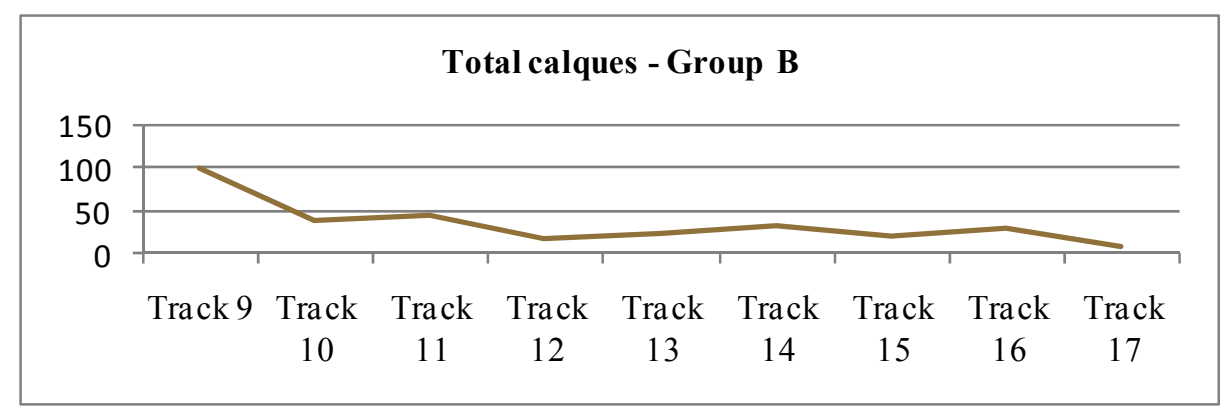

Figure 7. Number of calques produced by group B according to track (Tracks 9-17)

The highest number of calques is found in the first track (100 errors) and the lowest appears in the last track (8 errors). With a mean value of 34.6, the evolution of errors made by this group in each track plunges from track 9 to 10 . In the remaining tracks, this evolution does not reflect significant changes, except for a constant subtle drop down to the final track.

\section{Discussion}

The overall question here tested is whether Translation-based activities can contribute to generate a space to increase language awareness between the two languages involved so that the interplay promotes cross-linguistic cognitive processing and thus, plays a part in fostering literacy skills in L2 (English) students. For that purpose, this paper pursued four objectives. The first objective, consisting of reintroducing translation-based tasks as a viable teaching tool in Foreign Language Teaching (FLT) class, has been argued for in section 2, especially in 2.2. Current constructivist views of FLT give room toresort to L1 when necessary. Based on real performances, authentic materials, meaningful contents, contextualized tasks and taking into account functional aspects, translation activities definitely have a say in this space. Simultaneously, a student's personal background, real-world knowledge and participation are bound to play a decisive role in his knowledge construction process in current tertiary education contexts under the EHEA tenets, especiallywhen dealing with L2 acquisition. Thus, the holistic process of translating may boost the development of the metalinguistic awareness and metacognitive skills of students at different layers and wider ranges (Machida, 2011, p. 743).

Regarding the second objective, section 2.4 deals with the role of cross-linguistic interference in Second Language Acquisition (SLA) and highlights, following Krashen (1981), the two main consequences of this linguistic meddling: a positive transfer and a negative transfer. With the intention of taking advantage of erroneous executionsin the L2 as a chance to learn, this study focuses on the pernicious transfer of calque errors, as defined by Odlin (1993). Thus, a contrastive analysis between the original text and the translated text was carried out. This has allowed for the accomplishment of the third objective of identifying and tagging calque 
errors committed by students when performing inverse translations into L2. Therefore, the study of calque errors (detection and tagging) is here used not only as a way to improve the final translated text, but also as a way to understand those errors, not simply as unwanted phenomenon in language, and to use them as a source of information that can be used to upgrade the output in L2 (Carrió-Pastor y Mestre-Mestre, 2014, p. 99).

Finally, the data resulting from the practical exploration have been analysed to check whether this task triggers students' awareness of cross-linguistic differences and similarities and thus contributes to students' avoidanceof committing those calque errors again. Following Braga and Domínguez (2010) calque categorization and executing a bilingual revision (Mossop, 2001), calque errors were tagged and counted. This examination hasrevealed that despite the fact that morphological calques are ranked first in total numbers (Figure 1), it is actually a subtype of syntactical calques (word order) that accounts for the highest number of occurrences, followed by two morphological calques (verbal tenses and prepositions) (Figure 2). From that, it can reasonably be derived that syntactical structure calque errors are an obvious and direct consequence of the first language interference with learning L2. When faced with difficulties in a translation, students usually resort to their native language structures to convey content in L2. As surprisingly as it may seem for a technical text, lexical calques appear only in the forth position (Table 5), owing to wrong meaning extensions of actual specialized content units. Therefore, the shortlisted most common calques highlight the teaching aspects that deserve further attention and customization to address the pupils' specific needs (comprehension and usage of verbal tenses, for example, as shown in Figure 2 and Table 6).

As we are aware of the fact that groups A and B worked with different textual material, several inferences can be drawn from the calque error distribution. On the whole, calques show an uneven dispersion per group and track. Group A (tracks 0-8) displays no relevant lowering in the number of calques detected in each track (Figures 4 and 5). As no two students are the same, neither can their performances be. Amongst the reasons that explain these differences are personal previous linguistic competence and subject-specific knowledge may have exerted some influence on the students' performance and learning pace. This underlines the need to adjust the proficiency level of the task at hand to suit the students' needs in future practices. Conversely, group B displays a constant downward trend in the number of calques committed, registering 100 in the first track and only 8 in the last. The performance of this group (Figures 6 and 7) shows a marked downward trend in the evolution of the number of calques identified. As can be checked, the number of calque errors of every type descends steadily, demonstrating that the students' progressively avoid committing repeated and new calque errors.

This favourable piece of information, added to the majority of favorable opinions collected from all participants at the end of the project in an informal interview, back up the assertion that 'translating from L1 to L2 can be a powerful tool to develop language and literacy skills and increase metalinguistic awareness' (Cummins, 2007, p. 237) and hearten investigators to continue with this line of research.

Nonetheless, the results of this humble experience cannot be deemed conclusive evidence on the profitability and feasibility of using translation tasks in L2 classes, although they do show some promising findings that encourage further experimentation. While data collected in this hands-on task are of limited representativeness due to the text length, the number of participants, the translation type and the translation proficiency level, at the same time, the findings of this paper posses an undeniable value since their input stems from a real translation assignment made in professional-like conditions, and they are not derived from an ad-hoc laboratory experiment. Due to the positive conclusions extracted from this preliminary study, largerfigures and other text types will be included in the full-fledged study that is being designed and that will soon be implemented.

This leads to the conclusion that because each activity depends on the material with which operates, the development of consciousness is the development of a set of particular, independent capabilities or of a set of particular habits (Vygostky, 1987, p. 31)

Understood as a form-focused task and adequately adapted to the students'necessities, translation definitely has a say in FLT as a conscious-raising activity that contributes to develop students' written linguistic competency.

To conclude, from a linguistic perspective and understood as a form-focused task, adequately adapted to the students'necessities, translation can help students understand the morphological, lexical grammatical and syntactical similarities and differences between both languages (Leonardi, 2011) involved. And from a cognitive perspective, translation may function as a conscious-raising and scaffolding activity that contributes to develop students' writing capability and as a means of transference of metacognitive and metalinguistic strategies (Cummins, 2007, p. 233) between the languages involved. 


\section{References}

Alcaraz, E. (2000). El inglés profesional y académico. Madrid: Alianza.

Baker, C. (2000). A parents' and teachers' guide to bilingualism (2nd ed.). Clevedon, England: Multilingual Matters.

Braga, J., \& Domínguez, E. (2010). Calque-free lectures? Spanish cross-linguistic influence in content teaching through English. ELIA, Estudios de lingüistica inglesa aplicada, 10, 113-135. Retrieved from http://institucional.us.es/revistas/elia/10/7.Braga.pdf

Braga, J., \& Maíz, C. (2013). CLIL and Translation in Tertiary Education. Revista de Lenguas para Fines Especificos, 19, 29-59. Retrieved from http://www.webs.ulpgc.es/lfe/resources/3clilandtranslationintertiary educationRLFE19.pdf

Bransford, J. D., Brown, A. L., \& Cocking, R. R. (Eds.). (2000). How people learn: Brain, mind, experience, and school. Washington, D.C.: National Academy Press.

Brown, H. D. (2002). Principles of Language Learning and Teaching (4th ed.). New York: Longman.

Bygate, M., Skehan, P., \& Swain, M. (Eds.). (2001). Researching pedagogic tasks. London: Longman.

Cabré, M. T. (2004). Lenguajes especializados o lenguajes para propósitos específicos? In A. Van Hooft (Ed.), Textos y discursos de especialidad: El español de los negocios. Revista Foro Hispánico, 26, 19.

Carreres, A. (2006). Strange Bedfellows: Translation and Language Teaching into L2 in Modern Languages Degrees: Uses and Limitations. Proceedings of the Sixth Symposium on Translation, Terminology and Interpretation in Cuba and Canada. Canadian Translators, Terminologists and Interpreters Council (online) (pp. 1-21). Retrieved from http://www.cttic.org/ACTI/2006/papers/Carreres.pdf

Carrió Pastor, M. L. (2004). Contrastive analysis of scientific-technical discourse: Common writing errors and variations in the use of English as a non-native language. Ann Arbour: UMI.

Celce-Murcia, M. (2008). Rethinking the Role of Communicative Competence in Language Teaching. In E. Alcón, \& M. P. Safont (Eds.), Intercultural Language Use and Language Learning (pp. 41-57). Oxford/Cambridge: Oxford University Press/Cambridge University Press.

Cook, G. (2007). A thing of the future: translation in language learning. International Journal of Applied Linguistics, 17(3), 396-401. http://dx.doi.org/10.1111/j.1473-4192.2007.00160.x

Cook, G. (2010). Translation in Language Teaching: An Argument for Reassessment. Oxford: Oxford University Press.

Cook, V. (2001). Using the first language in the classroom. The Canadian Modern Language Review, 57(3), 402-423. http://dx.doi.org/10.3138/cmlr.57.3.402

Corder, S. P. (1974). Error Analysis. Oxford University Press: Oxford.

Cummins, J. (2000). Language, power, and pedagogy. Bilingual children in the crossfire. Clevedon, England: Multilingual Matters.

Cummins, J. (2001). Bilingual children's mother tongue: Why is it important for education? SPROG Forum, 15-20. Retrieved from http://www.iteachilearn.com/cummins/mother.htm

Cummins, J. (2007). Rethinking monolingual instructional strategies in multilingual classroom. Canadian Journal of Applied Linguistics, 10(2), 221-240.

Dafouz, E., \& Guerrini, M. C. (Eds.). (2009). CLIL across educational levels. Madrid: Richmond Publishing.

Duff, A. (1989). Translation. Oxford: OUP.

Duff, A. (1994). Translation: Resource Books for Teachers. Oxford: Oxford University Press.

Ellis, R. (2003). Task-based language teaching. Oxford, UK: Oxford University Press.

European Commission. (2013). Translation and language learning. The role of translation in the teaching of languages in the European Union: A study. Luxembourg: Publications Office of the European Union.

Haugen, E. (1953). The Norwegian language in America: A study in bilingual behavior. Vol. 1: The Bilingual Community; Vol. II: The American dialects of Norwegian. Bloomington: Indiana University Press.

Heydari, P., \& Bagheri, M. S. (2012). Error Analysis: Sources of L2 Learners' Errors. Theory and practice in language studies, 2(8), 1583-1589. Retrieved from http://dx.doi.org/10.4304/tpls.2.8.1583-1589 
Howatt, A. (1994). Ahistory of English language teaching. Oxford: Oxford University Press.

James, C. (1998). Errors in language learning and use: Exploring Error Analysis. London: Longman.

Kaweera, C. (2103). Writing Error: A Review of Interlingual and Intralingual Interference in EFL Context. English Language Teaching, 6(7), 9-18. http://dx.doi.org/10.5539/elt.v6n7p9

Kelly, N., \& Bruen, J. (2014). Translation as a pedagogical tool in the foreign language classroom: A qualitative study of attitudes and behaviours. Language Teaching Research, 16, 1-20. http://dx.doi.org/10.1177/ 1362168814541720

Krashen, S. D. (1981). Second Language acquisition and second language learning. California: Pergamon Press Inc.

Larsen-Freeman, D., \& Long, M. (1991). An introduction to second language research. London: Longman.

Lasagabaster, D., \& Ruiz de Zarobe, Y. (2010). CLIL in Spain: Implementation, results and teacher training. Newcastle upon Tyne: Cambridge Scholars Publishers.

Leonardi, V. (2010). The role of pedagogical translation in second language acquisition. Peter Lang: Bern.

Leonardi, V. (2011). Pedagogical Translation as a Naturally Occurring Cognitive and Linguistic Activity in Foreign Language Learning. Annali Online di Lettere-Ferrara, 1-2, 17-28. http://dx.doi.org/10.15160/ $1826-803 X / 234$

Long, M. (1985). A role for instruction in second language acquisition. In K. Hyltenstam, \& M. Pienemann (Eds.), Modelling and assessing second language Acquisition (pp. 77-99). Clevedon Avon: Multilingual Matters.

Machida, S. (2008). A step forward to using translation to teach a foreign/second language. Electronic journal of foreign language teaching, 5(1), 140-155. Retrieved from http://e-flt.nus.edu.sg/v5sp12008/machida.pdf

Machida, S. (2011). Translation in Teaching a Foreign (Second) Language: A Methodological Perspective. Journal of Language Teaching and Research, 2(4), 740-746. http://dx.doi.org/10.4304/j1tr.2.4.740-746

Malmkjær, K. (Ed.). (1998). Translation and Language Teaching: Language Teaching and Translation. Manchester. St. Jerome Publishing.

Martínez, R. (2012). An Experience on the Integration of ICT into a Teaching-learning Methodology of English as a Foreign Language. Journal of Language Teaching and Research, 3(2), 289-294. Retrieved from http://ojs.academypublisher.com/index.php/jltr/article/view/jltr0302289294

Mossop, B. (2001). Revising and Editing for Translators. Manchester: St. Jerome.

Newmark, P. (1999). Manual de traducción. Madrid: Cátedra.

Nord, C. (1997). Translating as a Purposeful Activity. Functionalist Approaches Explained (=Translation Theories Explained, 1). Manchester: St. Jerome.

Nord, C. (2006). Loyalty and Fidelity in Specialised Translation. Confluências: Revista de TraduçãoCientifica e Técnica, 4, 29-34.

Nunan, D. (2006). Task-based language teaching in the Asia context: Defining 'task'. In P. Robertson, \& J. Jung (Eds.), The Asian EFL Journal Quaterly, Special Conference Proceedings Volume: Task-based Learning in Asian Context (Vol. 8(3), pp. 12-18). Retrieved from http://www.asian-efl-journal.com/September_2006_ EBook_editions.pdf

Odlin, T. (1989). Language transfer: Cross-linguistic influence in language learning. Cambridge, UK: Cambridge University press.

Sager, J. C. (1989). Quality and Standards-The evaluation of translations. In C. Picken (Ed.), The Translators Handbook (2nd ed., pp. 91-102). Londres: Aslib.

Schaffner, C. (1998). Qualification for Professional Translators.Translation in Language Teaching Versus Teaching Translation. Manchester: St. Jerome publishing.

Vygotsky, L. S. (1978). Mind in society. Cambridge: Harvard University Press. 


\section{Notes}

Note 1. For further information about the survey, visit the website: http://ec.europa.eu/languages/policy/ strategic-framework/documents/language-survey-final-report_en.pdf

Note 2. For further information about the study Translation and language learning, visit the website: http://ec.europa.eu/dgs/translation/publications/studies/index_en.htm

Note 3. While lexical density is a key factor to distinguish between general and technical or specialized languages, other cognitive and pragmatic factors come into play in the realization of meaning of the specialized content lexical units (Cabré, 2004, p. 7; AlcarazVaró, 2000, p. 43).

Note 4. The level is approximately equivalent to B1 according to the Common European Framework of References for Languages (CFER). For more information, please visit: http://www.coe.int/t/dg4/linguistic/ cadre1_en.asp

Note 5. The definition has been taken from the On Line Oxford Dictionary available at: http://www.oxforddictionaries.com/definition/english/

\section{Appendix A}

The Number of morphological calques per type and track

\begin{tabular}{llllllllllllllllllll}
\hline Track/calque type & 0 & 1 & 2 & 3 & 4 & 5 & 6 & 7 & 8 & 9 & 10 & 11 & 12 & 13 & 14 & 15 & 16 & 17 & Total \\
\hline Article (MCa) & 4 & 0 & 16 & 4 & 0 & 4 & 0 & 0 & 4 & 4 & 0 & 8 & 0 & 4 & 4 & 4 & 4 & 0 & $\mathbf{6 0}$ \\
Adjectives (MCad) & 4 & 12 & 0 & 8 & 8 & 12 & 4 & 4 & 0 & 8 & 4 & 0 & 0 & 0 & 0 & 0 & 0 & 0 & $\mathbf{6 4}$ \\
Adverbs (MCadv) & 0 & 0 & 0 & 4 & 0 & 0 & 0 & 0 & 0 & 0 & 0 & 0 & 0 & 0 & 0 & 0 & 0 & 0 & $\mathbf{4}$ \\
Nouns (MCn) & 8 & 4 & 4 & 8 & 4 & 0 & 0 & 0 & 0 & 0 & 4 & 0 & 0 & 0 & 0 & 0 & 0 & 0 & $\mathbf{3 2}$ \\
Verb tenses (MCvt) & 20 & 8 & 8 & 4 & 4 & 8 & 8 & 12 & 4 & 16 & 4 & 12 & 0 & 0 & 4 & 0 & 4 & 4 & $\mathbf{1 2 0}$ \\
Pronouns (MCp) & 0 & 4 & 4 & 4 & 0 & 0 & 8 & 4 & 8 & 4 & 0 & 0 & 4 & 4 & 0 & 8 & 8 & 0 & $\mathbf{6 0}$ \\
Prepositions (MCpp) & 4 & 16 & 12 & 0 & 0 & 8 & 4 & 8 & 8 & 16 & 16 & 12 & 4 & 0 & 8 & 0 & 0 & 0 & $\mathbf{1 1 6}$ \\
\hline
\end{tabular}

\section{Appendix B}

The Number of syntactical calques per type and track

\begin{tabular}{llllllllllllllllllll}
\hline Track/calque type & 0 & 1 & 2 & 3 & 4 & 5 & 6 & 7 & 8 & 9 & 10 & 11 & 12 & 13 & 14 & 15 & 16 & 17 & Total \\
\hline Sentence link (SCsl) & 0 & 4 & 0 & 8 & 4 & 0 & 0 & 0 & 0 & 0 & 0 & 0 & 0 & 0 & 0 & 0 & 0 & 0 & $\mathbf{1 6}$ \\
Word order (SCwo) & 4 & 4 & 32 & 8 & 4 & 4 & 20 & 20 & 16 & 36 & 12 & 4 & 8 & 4 & 12 & 4 & 8 & 0 & $\mathbf{2 0 0}$ \\
\hline
\end{tabular}

\section{Appendix C}

The Number of lexical calques per type and track

\begin{tabular}{llllllllllllllllllll}
\hline Track/calque type & 0 & 1 & 2 & 3 & 4 & 5 & 6 & 7 & 8 & 9 & 10 & 11 & 12 & 13 & 14 & 15 & 16 & 17 & Total \\
\hline Extensions (LCe) & 4 & 0 & 8 & 8 & 0 & 4 & 4 & 12 & 12 & 12 & 0 & 4 & 0 & 12 & 4 & 4 & 4 & 4 & $\mathbf{9 6}$ \\
Creations (LCc) & 0 & 8 & 8 & 12 & 8 & 0 & 0 & 4 & 0 & 4 & 0 & 4 & 0 & 0 & 0 & 0 & 0 & 0 & $\mathbf{4 8}$ \\
\hline
\end{tabular}

\section{Copyrights}

Copyright for this article is retained by the author(s), with first publication rights granted to the journal.

This is an open-access article distributed under the terms and conditions of the Creative Commons Attribution license (http://creativecommons.org/licenses/by/3.0/). 